\title{
EFFECT OF FOLIAR POTASSIUM, MAGNESIUM AND BORON ON YIELD AND QUALITY OF SUGAR BEET (Beta vulgaris, L.)GROWING IN NEW RECLAIMED SOILS \\ Abo El-Hamd, A.S. ${ }^{1}$ and A.A. Esmail ${ }^{2}$ \\ 1- Dept. Agron., Fac. Agric. Al-Azhar Univ., Assiut. \\ 2- Dept. Environ., Fac. Agric. El-Minia University
}

\begin{abstract}
Tow Field Experiments were carried out at EL-Itizaz village, Samalout district, EL-Minia Governorate, Egypt during 2004/2005 and 2005/2006 seasons to study the effect of foliar with potassium, magnesium and boron individaly and combined on yield and quality of sugar beet. The experiment included 15 treatments which were the combinations of two levels from each of foliar potassium 1 and 2 Liter $36 \% \mathrm{~K}_{2} \mathrm{O} / \mathrm{fed}$, with 5.4 and $10.8 \mathrm{~kg} \mathrm{MgSo} / \mathrm{fed}$, boron (10 and $20 \mathrm{mg}$ boric acid/fed) and control (foliar spray with water). These treatments were arranged in randomized complete block design with 3 replications.

The obtained results indicated that spraying beet plants with $\mathrm{K}, \mathrm{Mg}$ or boron either solely or in combinations significantly increased root length, root diameter, root and foliage fresh weights per plant as well as roots, top and sugar yields/fed. The highest values of this traits resulted from the combinations between the three elements at higher concentrations. Also, foliar spray with $\mathrm{Mg}$ individual and the combinations between the three elements took the same trend for root/top ratio in both seasons. On the other hand, control treatment (without spraying) gave the maximum averages of sucrose and TSS percentages, while the highest values of purity\% resulted from foliar spray with the combinations between $\mathrm{K}, \mathrm{Mg}$ or $\mathrm{B}$ at lower concentrations in both seasons.

It, could be concluded that under the conditions of this study the highest roots and sugar yields can be produced by using foliar spray with the combinations.
\end{abstract}

\section{INTRODUCTION}

Recently, sugar beet crop has an important position in Egypt crop rotation as a winter crop not only in the fertile soils but also in poor, saline, alkaline and calcareous soils whereas, it could be economically grown in the newly reclaimed soils. Potassium fertilizer plays an important role in physiological processes in beet plants, where it proves juice quality and sugar yield. Also, potassium may play part in maintenance of turgor in plant cells as well as in the formation of sugar and in the enhancement of diseases resistance (Lawton and Cook, 1954). Dahdoh et al. (1988) showed that roots, top and sugar yields of sugar beet significantly increased with the application of potassium, Zinc and Phosphorus either added solely or in combinations. Bizlk (1993) concluded that a liquid fertilizer spray containing Kand Mg increased sugar contents. Pardo and Guadalix (1993) reported that potassium increased roots and sugar yields. Saif, Laila (2000), Esmail et al. (2002), Hassanin, Magde (2002), Ahmed (2005) and Esmail and Abo ELHamd (2007) stated that top, roots and sugar yields increased with increasing $\mathrm{K}$ level up to $48 \mathrm{~kg} \mathrm{~K} 2 \mathrm{O} / \mathrm{fed}$. 
Magnesium content of most soils generally lies in the range of between 0.05 for sandy soils and 0.5 for clay soils. Some magnesium occurs in soil in association with organic matter, but this fraction is usually small and less than $1.0 \%$ of the total soil magnesium, (Tisdal and Nelson, 1975) and Mengel and Kirkbp, 1982). Domska (1996) found that application of $60 \mathrm{~kg} \mathrm{MgO} / \mathrm{ha}$ as soil application and foliar $2 \mathrm{~kg} \mathrm{MgO} / \mathrm{ha}$ to sugar beet plants gave the highest sugar yield and sugar content. Barlog and Grzebisz (2001) pointed out that application of $0.5 \mathrm{~kg} \mathrm{MgO} / \mathrm{ha}$ increased root yield by $9.9 \%$ as compared with control (without $\mathrm{Mg}$ foliar application). Ahmed (2005) reported that $\mathrm{K}$ and $\mathrm{Mg}$ either solely or in combinations as well as boron in combinations increase growth parameters (root and foliage fresh weights/plant, root length, root diameter and root/top ratio and added that greatest values of roots, top and sugar yields resulted from foliar spray by combining with $\mathrm{Mg}$ and $\mathrm{B}$.

Sugar beet have higher requirement for boron than many ether crops, Boron may have a vital role in sugar translocation Mohmoud (1999).

Regarding the effect of boron fertilizer, Rizk et al. (1995) stated that application of moderate level of boron $(1.0 \mathrm{~kg} \mathrm{~B} / \mathrm{fed})$ resulted in higher increase of fresh and dry weights of tops and root/plant. Mohmoud (1999) concluded that sugar yield/fed was increased by about 4.5 ton/fed by foliar boron application at the rate of $2.5 \mathrm{~g} / \mathrm{fed}$. Gezegen et al. (2001) showed that root yield and refined sugar yield of sugar beet were increased by treated soil and leaf with boron at $0.3 \mathrm{~kg} / \mathrm{ha}$. On the other hand, increasing rates of boron by the same methods to the soil decreased the root and refined sugar yields. Hussein (2002) showed that the higher root and sugar yields were obtained with the application of boron at $6.0 \mathrm{mg} / \mathrm{k}$ soil

This work was initiated to investigate the effect of potassium, magnesium and boron and their combinations on yield and quality of sugar beet.

\section{MATERIALS AND METHODS}

Two field experiments were conducted at EL-Itizaz village, Samalout district, EL-Minia Governorate in 2004/2005 and 2005/2006 seasons to study the effect of potassium, magnesium and boron as well as their combinations on yield and quality of sugar beet. The soil texture of the experimental site was sandy-Loam having $33.88 \%$ coarse sand, $55.92 \%$ fine sand, $4.65 \%$ silt, $5.55 \%$ clay, $0.56 \%$ organic mater, $0.14 \%$ total $\mathrm{N}, 8.1 \mathrm{PH}, 85 \mathrm{ppm}$ available $\mathrm{N}$, $16 \mathrm{ppm}$ available $\mathrm{P}, 128 \mathrm{ppm}$ available $\mathrm{K}, 0.88 \mathrm{ppm}$ total boron, 0.42 available $\mathrm{mg}^{++}$(meg/100g. soil), $3.85 \% \mathrm{CaCo}_{3}$ and $10.3 \mathrm{mmoh} / \mathrm{cm} \mathrm{E.C.}$

A multigerm sugar beet cultivar Paleno was planted on October $3^{\text {th }}$ and $5^{\text {th }}$ in the first and second seasons, respectively. The experiment involved 15 treatments arranged in a randomized complete block design with three replications. The experimental basic unit area included six rides, each of $60 \mathrm{~cm}$ width and $4 \mathrm{~m}$ length occupying an area of $14.4 \mathrm{~m}^{2}$. Spacing between hills were $20 \mathrm{~cm}$. At 60 and 75 days from sowing, plants were sprayed with the following: 
1. Foliar spray with distilled water (control).

2. Foliar spray with potassium at the rate of $1 \mathrm{Liter} 36 \% \mathrm{~K}_{2} \mathrm{O} / \mathrm{fed}\left(\mathrm{K}_{1}\right)$.

3. Foliar spray with potassium at the rate of $2 \mathrm{Liter} 36 \% \mathrm{~K}_{2} \mathrm{O} / \mathrm{fed}\left(\mathrm{K}_{2}\right)$.

4. Foliar spray with $0.6 \% \mathrm{MgSO}_{4}$ equal $5.4 \mathrm{Kg} \mathrm{MgSO} / \mathrm{fed}\left(\mathrm{Mg}_{1}\right)$.

5. Foliar spray with $1.2 \% \mathrm{MgSO}_{4}$ equal $10.8 \mathrm{Kg} \mathrm{MgSO}_{4} / \mathrm{fed}\left(\mathrm{Mg}_{1}\right)$.

6. Foliar spray with $10 \mathrm{mg} \mathrm{L}^{-1}$ boric acid $\left(\mathrm{B}_{1}\right)$.

7. Foliar spray with $20 \mathrm{mg} \mathrm{L}^{-1}$ boric acid $\left(\mathrm{B}_{2}\right)$.

8. Foliar spray with $\mathrm{K}_{1}$ combined with $\mathrm{Mg}_{1}$ and $\mathrm{B}_{1}$.

9. Foliar spray with $K_{1}$ combined with $\mathrm{Mg}_{2}$ and $\mathrm{B}_{1}$.

10. Foliar spray with $\mathrm{K}_{1}$ combined with $\mathrm{Mg}_{1}$ and $\mathrm{B}_{2}$.

11. Foliar spray with $\mathrm{K}_{1}$ combined with $\mathrm{Mg}_{2}$ and $\mathrm{B}_{2}$.

12. Foliar spray with $K_{2}$ combined with $M g_{1}$ and $B_{1}$.

13. Foliar spray with $\mathrm{K}_{2}$ combined with $\mathrm{Mg}_{2}$ and $\mathrm{B}_{1}$.

14. Foliar spray with $\mathrm{K}_{2}$ combined with $\mathrm{Mg}_{1}$ and $\mathrm{B}_{2}$.

15. Foliar spray with $\mathrm{K}_{2}$ combined with $\mathrm{Mg}_{2}$ and $\mathrm{B}_{2}$.

Nitrogen fertilizer was applied at $80 \mathrm{~kg} \mathrm{~N} / \mathrm{fed}$ as ammonium nitrate $(33.5 \% \mathrm{~N})$ in two equal doses, the first was added after thinning, while the second one was added one month later. Phosphate fertilizer applied at seedbed preparation at $30 \mathrm{~kg} \mathrm{P}_{2} \mathrm{O}_{5} / \mathrm{fed}$ as calicium super phosphate $(15.5 \%$ $\mathrm{P}_{2} \mathrm{O}_{5}$ ). The other cultural practices done as recommended in the region.

At harvest time a sample of five plants were chosen at random from outer ridges to estimate yield components and juice quality characters as follows:

1. Root length $(\mathrm{cm})$.

2. Root diameter $(\mathrm{cm})$.

3. Root fresh weight/plant (g).

4. Foliage fresh weight/plant (g).

5. Root/top ratio.

6. Total soluble solids percentage (TSS\%) of roots it was measured in juice of fresh root using hand refract meter.

7. Sucrose percentage (pol\%) it was polarimeterically determined according to the methods of Le Docte (1927).

8. Juice Purity percentage \% it was calculated according to the following.

Juice purity $\%=$ sucrose $\%$ xTSS $\% / 100$.

At harvest sugar beet plants from the two inner ridges were calculated and cleaned roots and tops were separated and weighted in $\mathrm{kg}$, then converted to estimate:

1. Root yield (ton/fed).

2. Top yield (ton/fed).

3. Sugar yield ton/fed, it was computed according to the following formula.

Sugar yield $=$ Recovery sugar $\times$ root yield $/ 100$

Recovery sugar $=(S-0.4)(B-S) \times 0.73$

Where $\mathrm{S}=$ sucrose $\% \mathrm{~B}=\mathrm{TSS} \%$.

The obtained data of both seasons were tabulated and statistically analyzed according to Snedecor and Cochran (1981) and means were compared using LSD at $5 \%$ level. 


\section{RESULTS AND DISCUSSION}

\section{Root length and root diameter}

Data presented in Table 1 reveal that either spraying beet leaves with $\mathrm{K}, \mathrm{Mg}$ or B solely or combinations significantly increased root length and root diameter as compared with control, this held true in both seasons. Results in Table 1 detect that the combination between the three elements at higher concentration produced the highest means of root length and root diameter in booth seasons. On the other hand, no significant differences between $\mathrm{K}$ and higher concentration combined with $\mathrm{Mg}$ and $\mathrm{B}$ at both concentrations for root diameter in the first season. The increase in root length and root diameter may be due to the important role of potassium photosynthesis through carbohydrate metabolism, osmotic regulation and improves the autritonal balance and encourages dry matter accumulation as well as translocation of sugar and carbohydrates El-Shafai (1991). Also, the role magnesium for increment photosynthesis operation and consequently the assimilation, translocation and storage capacity, also its role in stimulating cell division and elongation El-Taweel, Fayza (1999). As well as the role of boron in playing a vital role in sugar transportation from green leaves to the storage cells in the root. Similar results were recorded by El-Taweel (1999) and Osman (2005).

2. Root and foliage fresh weights/plant.

Data presented in Table (1) reveal that foliar spray with $\mathrm{K}$ and $\mathrm{Mg}$ as well as $B$ at both concentrations significantly increased averages of fresh weights of root and foliage/plant at harvest as compared to control. Mg was more effective than either $\mathrm{K}$ or $\mathrm{B}$ on all studied growth traits.

Regarding with the combinations between the three elements at the two concentrations were significantly increased the means of fresh weights of root and foliage/plant as compared with control, while the higher concentration gave the highest values of this treaties as compared with other treatments. This held true in both seasons. This results could be attributed to that the important of $\mathrm{K}$ in physiological processes in plant such as translocation of sugar and carbohydrates. On the other side, the positive effect of Mg may be due to cells division and its role in absorbing phosphorus and activation photosynthesis. Also, the results could be attributed to that $B$ is an essential element for photosynthetic pigmets where it increases rate of photo synthetic $\mathrm{U}_{2}$ evolution and $\mathrm{CO}_{2}$ fixation. At the same time it decreases the activates of oxidative pentose phosphate enzymes and respiration Garcia-Gonzalez et al. (1990), Rizk et al. (1993), El-Taweel, Fayza (1999), Ahmed (2005) and Moustafa, Zeinab et al. (2006), revealed the beneficial effect of both $\mathrm{K}, \mathrm{Mg}$ and $\mathrm{B}$ on growth and some quality characteristics of sugar beet plants.

\section{Root/top ratio.}

Results given in Table 1 indicated that foliar spray with $\mathrm{Mg}$ individual significant increased root/top ratio, while spraying $\mathrm{K}$ and B Solely decreased root/top ratio, but the differences did not reach to the level of significant as compared with control in both seasons. On the other hand, foliar spray with 
the combination between the three elements significantly increased root/top ratio. The highest average resulted from spraying with $\mathrm{K}$ combined with $\mathrm{Mg}$ and $B$ at higher concentration in the first season and from spraying $K$ and at higher concentration combined with $\mathrm{Mg}$ at the two concentration in the second season. Similar results were obtained by El-Taweel, Fayza (1999), Ahmed (2005) and Osman. (2005).

\section{Sucrose $\%$ and TSS\%.}

Data in Table 2 showed that the control treatment (with out foliar spray) gave the highest values of Sucrose\% and TSS\%. On the other hand foliar spraying with $\mathrm{K}, \mathrm{Mg}$ or B either solely or in combination significantly decreased sucrose and TSS\%, this held true in both seasons. Similar results were obtained by Abd El-Gawad et al. (2004), Ahmed (2005), Mohamed (2005), Hassanin (2002 and Osman (2005).

\section{Purity\%.}

Results in Table 2 indicated that foliar spray with $\mathrm{K}, \mathrm{Mg}$ or B solely at both concentrations had no significant effect on purity\% in both seasons. On the other hand, the combination between the $\mathrm{K}$ and $\mathrm{B}$ at low concentrations combined with $\mathrm{Mg}$ at both concentrations recorded the highest values for purity\% in both seasons.

\section{Root, top and sugar yields (ton/fed).}

Results recorded in Table (2) show that spraying K, Mg or B solely at both concentration promoted roots, tops and sugar yields as compared to control treatment, the increases were significantly in both seasons. The highest values of root, tops and sugar yields resulted from the combination between the three elements at higher concentration in both seasons, but no significant differences between foliar spray with $\mathrm{K}$ at higher concentration combined with $\mathrm{Mg}$ and $\mathrm{B}$ at both concentration for sugar yield in the second season. The increase in roots, tops and sugar yields were $(78.69 \%, 41.82 \%$ and $85 \%)$ as well as $(73.54 \%, 51.58 \%$ and $48.21 \%)$ as compared with control treatment in the first and second seasons, respectively. The superiority of yield by $\mathrm{K} 1 \mathrm{Mg}$ and $\mathrm{B}$ might be attribute to their roles in increasing growth traits as mentioned before which finally reflected in better yields. Moreover, B nutrition trends to maintain sugar is easily trans located soluble forms and increasing synthesis of sucrose and subsequently increasing sugar yield. (Omran et al., 2002). These results stand in harmony with those recorded by Pardo and Guadlix (1993), El-Moursy et al. (1998), Barlog and Grzebize (2001), Ortovius et al. (2001), Barlog et al. (2002), Nafei (2004), Mohamed (2005), Moustafa et al. (2006) and Esmail and Abo El-Hamd (2007). 
Abo EL-Hamd, A.S. and A.A. Esmail

T1

1742 
J. Agric. Sci. Mansoura Univ., 33 (3), March, 2008

t2

1743 


\section{REFERENCES}

Abd EL-Gawad, A.M.N.; S.A.H. Allam; L.M.A. Seif and A.M.H Osman (2004). Effect of some micronutrients on yield and quality of sugar beet (Beta vulgaris, L.). Egypt. J. Agric. Res., 8(4):

Ahmed, A.F. (2005). Effect of potassium, magnesium and boron on sugar beet yield and quality grown in the newly reclaimed soils. M.Sc. Thesis, Fac. of Agric., Minia, Univ., Egypt.

Barlog, P. and W. Grzebisz (2001). Effect of magnesium foliar application on the yield and quality of sugar beet roots. Rostlinna Vyroba, 2001 47(9): 418-422. (CAB Abstracts 2000- 2002).

Barlog, P.; W. Grzebisz and A. Paradowski (2002). Effect of potassium, sodium and magnesium fertilization on yielding of three sugar beet varieties. Part 1- yield of root and sugar Efektywna uprawa barke cukrowego, Proceeding of Conference. Poznan, Poland 24-26 June 2002 Biuletyn Enstytutu Hodo Wlit Aklimatyzacji Roslin 222: 119-126. (CAB Abstracts 2002- 2003).

Bizlk, J. (1993). The content and rates of cat ions in sugar beet plants as an indicator of sugar content. Rostt. Vyro, 39(12): 1103-1109 (C.F. field crop Abst., 4868 6070, 1995).

Dahdoh, M.S.A.; R.N. Kamb; M.A. EL-Hassanin and A.S. EL-Hassanin (1988). The productivity of sugar beet grown in calcareous soils with regard to Zn, P and K fertilization. Desert Insti. Bull, A.R.E., 38(2): 382390.

Domska, D. (1996). Yield and quality of sugar beet after foliar feeding with nitrogen, magnesium, boron and copper. Polish J. of Fead anf Nutri Sci. 5(20): 23-31 (C.F. felid Crop Abst., 50 (4): 2488, 1997).

EL-Moursy, S.A.; A.T. EL-Kassaby; A.M. Salama and H.A. Sarahan (1998). Macro elements requirements of sugar beet. J. Agric. Sci. Mansoura Univ., 23(8): 701-710.

EL-Safai, A.M.A. (1991). Effect of some agronomic trements on yield and quality of sugar beet under Kafr EL-Sheikh region. M.Sc. Thesis, Fac. Of Agric., Ain Shams, Univ., Egypt

EL-Taweel, Fayza, M.A. (1999). Response of some sugar beet varieties to potassium and magnesium fertilizers. Ph.D. Thesis, Fac. Of Agric., Zagazig, Univ., (Banha Branch), Egypt.

Esmail, A.A. and A.E. Abo EL-Hamd (2007). Effect of sowing date, plant density and potassium fertilization on yield and quality of sugar beet ((Beta vulgaris, L.). J. Agric. Sci. Mansoura Univ., 32(3): 1127-1638.

Esmail, A.M.A.; Kh.A. Aboushady and A.M. Allam (2002). Response of some sugar beet varieties to methods of potassium application. Egypt. J. Appl. Sci., 17(2): 86-101.

Garcia-Gonzalez, M.; P. Mateo and I. Bonitte (1990). Effect of boron deficiency on photosynthesis and reducent sucrose and their relationship with nitrogen, activity in anabaeana. Pee 7119 Plant Physio., 660-665. 
Gezegen, S.; M. Hamurcu and M. Apaydin (2001). Effect of boron application on the yield and quality of sugar beet. Turksh J. of Agric. and Forestry 25(2): 89-95. (CAB Abstracts 2000 - 2002).

Hussein, Magda, A. (2002). Effect of boron on the yield, element control and quality characteristics of sugar beet grown in calcarcous soil amended with sulfur. Alex. Univ. J. Agric. Res. 47(2): 201-207.

Lawton, K. and R.L. Cook (1954). Potassium in plant nutrition. Advances in Agronomy. (VI): 253-303

Le-Docte, A. (1927). Commercial determination of sugar in beet root using the saches- Ic Doct process Int. Sugar. J., 29, 488-492.

Mengel, K. and E.A. Kirkby (1982). Principles of plant nutrition prentice fnternatinal Potash Institutc, Switzer land.

Mohamed, M.S. (2005). Study of some factors affecting productivity of sugar beet. Ph.D. Thesis Fac. of Agric. AL-Azhar, Univ., Egypt.

Mohmoud, S.A. (1999). Effect of boron fertilization on yield of sugar beet growth in saline alkali soils. Fayoum J. Res. Dev., 13(1): 15-20.

Moustafa, Zeinab, R.; Safaa, S.M. EL-Sayed; Shafika, N. Moustafa and A.M,E. Gomaa (2006). Physio-chemical Properties, quality and yields as affected foliar spray with boron and sulfur in sugar beet plants. Meinafiya J. Agric. Res., 31(4): 957-970.

Nafei, A.I. (2004). Effect of nitrogen and boron fertilization level on yield and quality of sugar beet grown in Upper Egypt. Egypt. J. Appl. Sci., 19(2): 48-57.

Omran, Samia, E.H.; EL-Guibali, H. Amal and K.L.A. Abou-Shady (2002). Effect of zinc and boron application at different rates and methods on sugar beet plants. Ann. of Agric. Sci. Moshtohor, 40: 1865-1875.

Ortovius, K.; W.J. Horst; M.K. Sehenk; A. Burkert; N. Claassen; H. Flessa; W.B. Frommer; H. Goldbach; H.W. Olfs and V. Romheld (2001). Effect of foliar fertilization with magnesium sulfur and boron to sugar bee, oil seed rape and cereal. Plant Nutrition Food Security and Sustain ability of agro- ecosystems through basic and applied research. Fourth international Plant Nutrition Colloyuim, Hannover Germany, 788-789. (CAB Abstracts 2000 - 2002).

Osman, M.S.H. (2005). Effect of potassium and magnesium on yield and quality of two sugar beet varieties. Egypt. J. Agric. Res., 83(1): 215228.

Pardo, M.T. and M.E. Guadalix (1993). Effect of nitrogen and potassium fertilization on yield, sucrose percentage and juice purity of sugar beet Potash Review, Subject 7(2): 1993, Root and tuber crops, $6^{\text {th }}$ Surte: 1 7.

Rizk, S.A.M.; M.A.M. Sherif and A.A. Sakr (1995). Effect of nitrogen and boron supply in highly calcareous soil on the growth and yield of sugar beet. Zagazig J. Agric. Res., 22(4): 1157-1166.

Saif Laila M.A. (2000). The relative importance of potassium fertilizer for sugar beet under Upper Egypt conditions. Menufiya Univ. J.Agric. Res., 25: 1215-1227.

Snedecor, G.W. and W.G. Cochran (1981). Statistical Methods. Seventh Ed. lowa State Univ. Press, Ames, lowa, USA. 
Tisdal, S.I. and W.L. Nelson (1975). Soil fertility and fertilizer. Macmillan Publishing Co., Inc. United States of American.

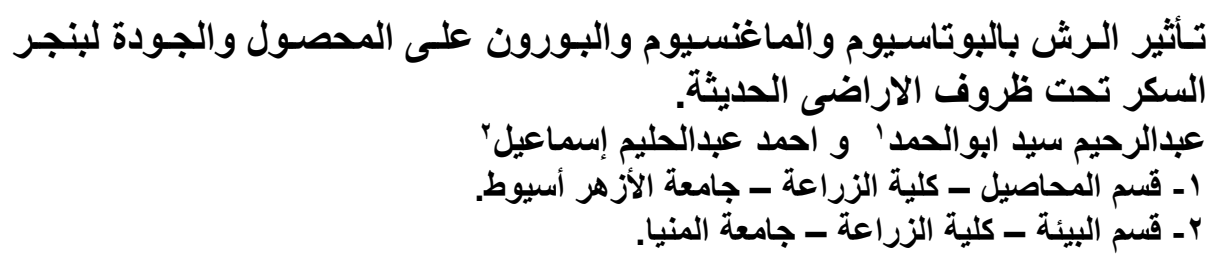

أقيمت تجربتان حقليتان فى تصميم القطاعات الكاملة العشوائية فى ثلاث مكرارت بقاث بقرية

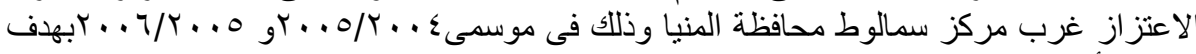

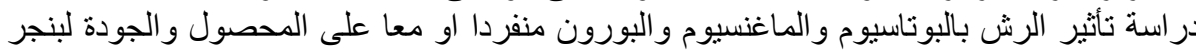

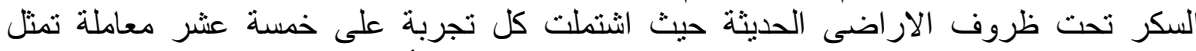

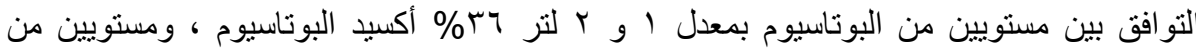

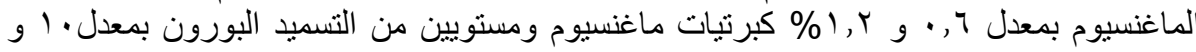

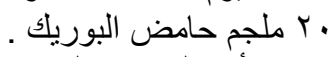

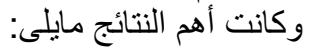

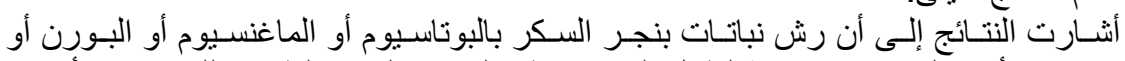

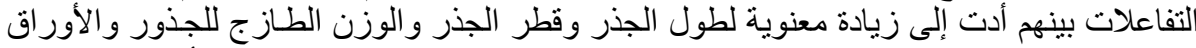

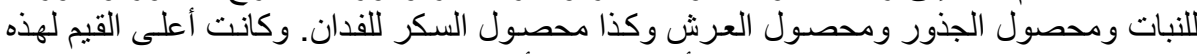

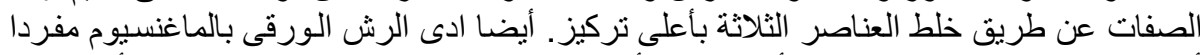

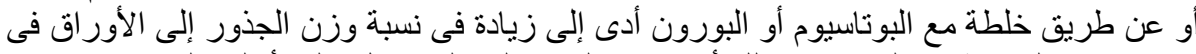

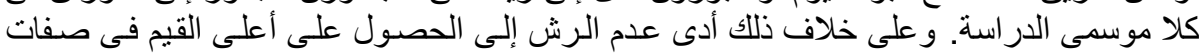

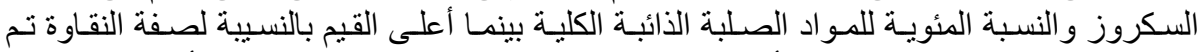
الحصول عليها باستخدام التركيز الأقل من العناصر الثلاثة (البوتاسيوم و الماغنسيوم أو البورون) فى لئي

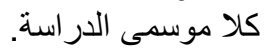

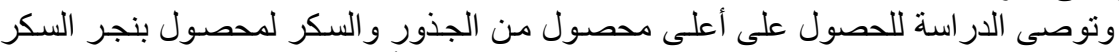
الرش بمخلوط العناصر الثلاثة (بوتاسيوم و ماعنسيوم و بورون) بأعلى تركيز. 
Table 1: Average of root length, root diameter, root fresh weight/plant (g), foliage fresh weight/plant (g) and root/top ratio as affected by potassium, magnesium and boron fertilization on sugar beet during 2004/2005 and 2005/2006 seasons.

\begin{tabular}{|c|c|c|c|c|c|c|c|c|c|c|}
\hline \multirow[b]{2}{*}{ Treatments } & \multicolumn{2}{|c|}{ Root length (cm) } & \multicolumn{2}{|c|}{$\begin{array}{l}\text { Root diameter } \\
(\mathrm{cm})\end{array}$} & \multicolumn{2}{|c|}{\begin{tabular}{|c|} 
Root fresh weight per \\
plant (gm)
\end{tabular}} & \multicolumn{2}{|c|}{$\begin{array}{l}\text { Foliage fresh weight } \\
\text { per plant (gm) }\end{array}$} & \multicolumn{2}{|c|}{$\begin{array}{c}\text { Root } / \text { top } \\
\text { ratio }\end{array}$} \\
\hline & $2004 / 05$ & $2005 / 06$ & $2004 / 05$ & $2005 / 06$ & $2004 / 05$ & $2005 / 06$ & $2004 / 05$ & $2005 / 06$ & $2004 / 05$ & $2005 / 1$ \\
\hline Control & 12.93 & 14.73 & 7.16 & 7.30 & 506.67 & 533.33 & 204.33 & 208.33 & 2.48 & 2.50 \\
\hline Folair spray with $\mathrm{K}_{1}$ & 15.60 & 15.70 & 7.50 & 7.67 & 560.00 & 590.00 & 227.33 & 231.33 & 2.48 & 2.50 \\
\hline Folair spray with $\mathrm{K}_{2}$ & 17.80 & 17.97 & 7.96 & 8.13 & 587.33 & 620.00 & 247.33 & 251.00 & 2.38 & 2.40 \\
\hline Folair spray with $\mathrm{Mg}_{1}$ & 18.53 & 18.67 & 8.10 & 8.27 & 605.67 & 676.67 & 240.00 & 245.67 & 2.52 & 2.70 \\
\hline Folair spray with $\mathbf{M g}_{2}$ & 19.03 & 19.23 & 7.63 & 7.87 & 654.33 & 692.33 & 247.00 & 252.33 & 2.65 & 2.70 \\
\hline Folair spray with $\mathrm{B}_{1}$ & 14.36 & 15.30 & 7.83 & 8.03 & 527.67 & 554.00 & 217.33 & 224.00 & 2.43 & 2.40 \\
\hline Folair spray with $\mathrm{B}_{2}$ & 15.36 & 15.67 & 8.60 & 8.83 & 545.00 & 570.07 & 227.66 & 233.00 & 2.39 & 2.60 \\
\hline Folair spray with $\mathrm{K}_{1} \mathrm{Mg}_{1} \mathrm{~B}_{1}$ & 20.90 & 21.13 & 8.93 & 9.13 & 682.67 & 707.33 & 258.33 & 265.67 & 2.64 & 2.60 \\
\hline Folair spray with $\mathrm{K}_{1} \mathrm{Mg}_{2} \mathrm{~B}_{1}$ & 21.43 & 21.73 & 9.10 & 9.37 & 706.67 & 729.67 & 266.00 & 273.00 & 2.65 & 2.60 \\
\hline Folair spray with $\mathrm{K}_{1} \mathrm{Mg}_{1} \mathrm{~B}_{2}$ & 21.93 & 22.30 & 9.36 & 9.63 & 710.66 & 745.33 & 265.66 & 270.00 & 2.67 & 2.70 \\
\hline Folair spray with $\mathrm{K}_{1} \mathrm{Mg}_{2} \mathrm{~B}_{2}$ & 22.56 & 23.03 & 9.53 & 9.87 & 750.33 & 765.00 & 279.66 & 285.33 & 2.68 & 2.60 \\
\hline Folair spray with $\mathrm{K}_{2} \mathrm{Mg}_{1} \mathrm{~B}_{1}$ & 24.60 & 24.67 & 9.83 & 10.10 & 776.33 & 791.17 & 276.33 & 287.67 & 2.81 & 2.70 \\
\hline Folair spray with $\mathrm{K}_{2} \mathrm{Mg}_{2} \mathrm{~B}_{1}$ & 25.56 & 25.80 & 10.00 & 10.23 & 822.33 & 830.17 & 282.33 & 287.33 & 2.91 & 2.80 \\
\hline Folair spray with $\mathrm{K}_{2} \mathrm{Mg}_{1} \mathrm{~B}_{2}$ & 26.16 & 26.50 & 10.06 & 10.30 & 855.33 & 880.00 & 280.33 & 299.00 & 3.06 & 2.90 \\
\hline Folair spray with $\mathrm{K}_{2} \mathrm{Mg}_{2} \mathrm{~B}_{2}$ & 26.80 & 27.40 & 10.26 & 10.73 & 905.00 & 925.67 & 289.66 & 315.67 & 3.18 & 2.90 \\
\hline F test $\quad$ LSD at ${ }_{0.05 \%}$ & 0.41 & 0.41 & 0.24 & 0.24 & 15.20 & 10.76 & 4.08 & 4.51 & 0.12 & 0.11 \\
\hline
\end{tabular}

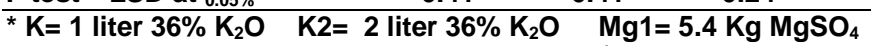
$\mathrm{Mg} 2=10.8 \mathrm{Kg} \mathrm{MgSO}_{4} \quad \mathrm{B1}=10 \mathrm{mg} \mathrm{L}^{-1}$ boric acid B2=20 $\mathrm{mg} \mathrm{L}^{-1}$ boric acid 
Table 2: Average of sucrose $\%$, TSS $\%$ and Purity $\%$, root yield (ton/fed), top yield (ton/fed) and sugar yield (ton/fed as affected by potassium, magnesium and boron fertilization on sugar beet during 2004/2005 and 2005/2006 seasons.

\begin{tabular}{|c|c|c|c|c|c|c|c|c|c|c|c|c|}
\hline \multirow{2}{*}{ Treatments Characters } & \multicolumn{2}{|c|}{ Sucrose $\%$} & \multicolumn{2}{|c|}{ TSS $\%$} & \multicolumn{2}{|c|}{ Purity\% } & \multicolumn{2}{|c|}{$\begin{array}{l}\text { Root yield } \\
\text { (ton/fed) }\end{array}$} & \multicolumn{2}{|c|}{$\begin{array}{l}\text { Top yield } \\
\text { (ton/fed) }\end{array}$} & \multicolumn{2}{|c|}{$\begin{array}{c}\text { Sugar yiel } \\
\text { (ton/fed) }\end{array}$} \\
\hline & $2004 / 05$ & $2005 / 06$ & $2004 / 05$ & $2005 / 06$ & $2004 / 05$ & $2005 / 06$ & $2004 / 05$ & $2005 / 06$ & $2004 / 05$ & $005 / 06$ & $004 /$ & 0 \\
\hline Control & & 18.00 & 21.77 & 21.67 & 81.93 & & 17.73 & 18.67 & 7.15 & 7.29 & 3.16 & \\
\hline Folair spray with $\mathrm{K}_{1}$ & & & & & & & 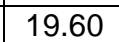 & 65 & 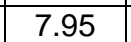 & 0 & & \\
\hline Folair s & & & & & & & & & 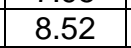 & 9 & & \\
\hline Folair s & & & & & & & & & 8.27 & 0 & & \\
\hline Folair s & & & & & & & & 24.23 & 8.64 & 8.83 & & \\
\hline Folair spray with $\mathbf{B}_{1}$ & & & & & & & & 39 & & 8.17 & & \\
\hline Folai & & & & & & & & & 7 & 9 & & \\
\hline spray & & & & & & & 23 & 24.76 & 0 & 9.30 & 4 & \\
\hline Folair spray v & & & & & & & 73 & 25.54 & 31 & .56 & 3.97 & \\
\hline Folair spray with $\mathrm{K}_{1}$ & & & & & & & 24.76 & 26.08 & 9.30 & 9.42 & 4.01 & \\
\hline Folair spray with r & & & & & & & 26.26 & 26.78 & 9.79 & 9.79 & 9 & \\
\hline Folair spraj & & & & & & & 27.17 & 27.59 & 9.67 & 10.67 & 4.22 & \\
\hline Folair spra & & & & & & & 28.78 & 28.96 & 9.88 & 10.06 & 4.37 & \\
\hline Folair spray wi & & & & & & & 30.04 & 30.08 & 9.81 & 10.47 & 4.68 & \\
\hline Folair spray with $\mathrm{K}_{2} \mathrm{Mg}_{2} \mathrm{~B}_{2}$ & 15.23 & 15.37 & 19.00 & 18.93 & 80 & & 31.67 & 32.40 & 10.14 & 11.05 & 4.83 & \\
\hline test LSD at 0. & 0.54 & 0.52 & 0.60 & 0.56 & 3.39 & 3.89 & 0.55 & 0.41 & 0.29 & 0.34 & 0.15 & \\
\hline
\end{tabular}

${ }^{*} \mathrm{~K}=1$ liter $36 \% \mathrm{~K}_{2} \mathrm{O} \quad \mathrm{K} 2=2$ liter $36 \% \mathrm{~K}_{2} \mathrm{O} \quad \mathrm{Mg}^{1}=5.4 \mathrm{Kg} \mathrm{MgSO}_{4}$

$\mathrm{Mg}_{2}=10.8 \mathrm{Kg} \mathrm{MgSO}_{4} \quad \mathrm{~B} 1=10 \mathrm{mg} \mathrm{L}^{-1}$ boric acid B2=20 mg L-1 boric acid 
J. Agric. Sci. Mansoura Univ., 33 (3), March, 2008

\begin{tabular}{l}
1738 \\
1739 \\
1740 \\
1741 \\
1742 \\
1743 \\
1744 \\
1745 \\
1746 \\
\hline 1738 \\
1739 \\
1740 \\
1741 \\
1742 \\
1743 \\
1744 \\
1745 \\
1746
\end{tabular}

